\title{
SGMS2 wt Allele
}

National Cancer Institute

\section{Source}

National Cancer Institute. SGMS2 wt Allele. NCI Thesaurus. Code C105025.

Human SGMS2 wild-type allele is located in the vicinity of $4 q 25$ and is approximately $90 \mathrm{~kb}$ in length. This allele, which encodes phosphatidylcholine:ceramide cholinephosphotransferase 2 protein, plays a role in cell growth. 